УДК: 352

DOI: https://doi.org/10.32689/2618-0065-2020-2(4)-118-134

Джафаров Руслан Фікрет огли, аспірант кафедри державного управління Київського національного університету імені Тараса Шевченка, Україна, 01601, місто Київ, вул. Володимирська, 64/13, тел.: 0938157677, еmail: Ruslan_D23@ukr.net, https//orcid.org/0000-0002-2380-252X

\title{
ВИЗНАЧЕННЯ ПРАВОВОГО СТАТУСУ ДЕПУТАТА МІСЦЕВОЇ РАДИ В ДЕРЖАВАХ-ЧЛЕНАХ ЄВРОПЕЙСЬКОГО СОЮЗУ: НАЦІОНАЛЬНІ ОСОБЛИВОСТІ ЄВРОПЕЙСЬКИХ КРАЇН ТА ПРОБЛЕМНІ ПИТАННЯ РЕАЛІЗАЦІЇ ДОСВІДУ В УКРАЇНІ
}

Анотація. У статті здійснено аналіз характерних особливостей визначення правового статусу депутата місцевої ради (органів місцевого самоврядування) в окремих держава-членах $\mathrm{CC}$ за теоретичним, функціональним і оціночним компонентами. Результати аналізу дали змогу встановити особливості визначення функцій, повноважень та відповідальності депутата місцевої ради; організації діяльності в напрямку ефективної взаємодії органів виконавчої влади та місцевого самоврядування в умовах децентралізації; оцінювання ефективності їх діяльності в окремих державахчленах Європейського Союзу.

Як відомо, в Україні проведення реформи децентралізації планується завершити до кінця 2020 року. В іiі основу закладено основні положення Європейської хартії місцевого самоврядування. Реформа передбачає впровадження стандартів організації управління на місцях, а також формування національної моделі місцевого самоврядування, виходячи 3 власних потреб та традицій. 3 огляду на проведений аналіз правового статусу депутата місцевої ради за теоретичним, функціональним та оціночним компонентами визначено такі проблемні питання, які потребують вирішення: наявність політизації діяльності депутатів місцевої ради та закріплення впливу на нього великих політичних партій національного масштабу; досить обмежене використання інструменту співробітництва між об'єднаними територіальними громадами; відсутність методологічних та інституційних засад оцінювання ефективності діяльності депутата місцевої ради. Для їх вирішення доцільно проаналізувати функції та повноваження депутата місцевої ради, що стосуються забезпечення реалізації національних інтересів та інтересів громади, а також ефективності їх діяльності; організації взаємодії депутата місцевої ради 3 іншими територіальними громадами, органами влади, що 
виконують функції контролю, а також 3 органами державної влади стратегічного рівня щодо реалізації національних інтересів.

Ключові слова: депутат місцевої ради; органи місцевого самоврядування, територіальна організація влади, адміністративна реформа, децентралізація.

Jafarov Ruslan Fikret Ogli, Postgraduate Student, Department of Public Administration, Taras Shevchenko National University of Kyiv, Ukraine, 01601, Kyiv, str. Volodymyrska, 64/13, tel .: 0938157677, https//orcid.org/0000-0002$2380-252 X$

\section{DETERMINATION OF THE LEGAL STATUS OF A DEPUTY IN THE MEMBER STATES OF THE EUROPEAN UNION: NATIONAL FEATURES OF THE EUROPEAN COUNTRIES AND PROBLEM ISSUES OF REALIZATION OF THE EXPERIENCE IN UKRAINE}

Abstracts. The article analyzes the peculiarities of determining the legal status of a deputy of the local council (local self-government bodies) in individual EU Member States by theoretical, functional and evaluation components. The results of the analysis made it possible to establish the specifics of determining the functions, powers and responsibilities of a deputy of the local council; organization of activities in the direction of effective interaction of executive authorities and local selfgovernment in the conditions of decentralization; assessing the effectiveness of their activities in individual Member States of the European Union.

It is known that decentralization reform is planned to be completed in Ukraine by the end of 2020. It is based on the main provisions of the European Charter of Local Self-Government. The reform envisages the introduction of standards of organization of local governance, as well as the formation of a national model of local self-government, based on their own needs and traditions. In view of the analysis of the legal status of a deputy of the local council by theoretical, functional and evaluation components, the following problematic issues are identified that need to be resolved: availability of politicization of the activity of the deputies of the local council and consolidation of influence on it by large political parties of national scale; rather limited use of the tool of cooperation between the united territorial communities; lack of methodological and institutional bases for assessing the effectiveness of the activity of a deputy of the local council. In order to resolve them, it is advisable to analyze the functions and powers of a deputy of the local council concerning the realization of national and community interests, as well as the effectiveness of their activities; organization of interaction of a deputy of the local council with other territorial communities, authorities performing the functions of control, as well as with bodies of state power at the strategic level regarding the realization of national interests. 
Keywords: deputy of the local council; local self-government bodies, territorial organization of government, administrative reform, decentralization.

Постановка проблеми. Імплементація Угоди про асоціацію між Україною та ЄС передбачає проведення ряду інституційних реформ в Україні, серед яких чільне місце займає реформа місцевого самоврядування та територіальної організації влади. В їх основу закладено положення Європейської хартії місцевого самоврядування, яка передбачає впровадження стандартів організації управління на місцях, а також формування національної моделі місцевого самоврядування, виходячи з власних потреб та традицій. Зважаючи на це, у країнах-членах $\mathrm{CC}$ формуються моделі місцевого самоврядування, які відрізняються між собою, внаслідок чого їх національні особливості набувають більшого значення. Тому порівняльна характеристика правового статусу депутата місцевої влади (органів місцевого самоврядування загалом) в державах-членах $\mathrm{CC}$ та визначення проблемних питань реформи децентралізації, що мають місце в Україні має актуальне значення, враховуючи необхідність подальшого впровадження в Україні кращих європейських практик у цій сфері.

Аналіз останніх досліджень і публікацій. На різних аспектах дослідження зарубіжного досвіду органів місцевого самоврядування загалом, у тому числі функціонування представницьких органів акцентували увагу багато науковців. Зокрема, зарубіжний досвід організації взаємодії між органами місцевого самоврядування у своїх працях досліджували О.Бориславська, І.Заверуха, А.Школик, Н.Шпортюк, О.Скороход, А.Лелеченко, Б.Копля (що стосується дослідження і врахування досвіду окремих держав-членів СС в процесі реформи децентралізації в Україні), М.Янішевський (досвід Німеччини), В.Нікітіна (досвід Італії). Досить широку бібліографію становлять праці аналітичного характеру, серед яких варто відмітити “Досвід децентралізації у країнах Свропи” (підготовлено фахівцями Інституту законодавства Верховної Ради України), "Local and Regional Governments in Europe. Structures and Competences" (Місцеві і регіональні уряди у Свропі. Структури та компетенції) (досліджено фахівцями європейської організації Council of European Municipalities and Regions), “Скандинавський шлях. Досвід реформ адміністративно-територіального устрою і місцевого самоврядування в Данії та Швеції” (підготовлено Інститутом громадянського суспільства). Незважаючи на це, недостатньо дослідженими залишаються питання дослідження статусу депутата місцевої ради в умовах реформи децентралізації та окремих його компонентів в державах-членах $\mathrm{CC}$ та проблемні питання впровадження досвіду в Україні.

Формулювання мети статті. Метою статті $є$ з'ясування характерних національних особливостей визначення правового статусу депутата місцевої 
ради (органів місцевого самоврядування) в державах-членах СС і в цьому контексті виокремлення проблемних питань реалізації їх досвіду в Україні.

Виклад основного матеріалу дослідження. Для визначення пріоритетів щодо удосконалення правового статусу депутата місцевої ради в контексті реформи децентралізації в Україні доцільно визначити можливості впровадження передового європейського досвіду на національних теренах окремо за компонентами. У нашому дослідженні [1] було обгрунтовано, що при аналізі правового статусу депутата місцевої ради можна виділити такі компоненти: теоретичну (лежить в основі визначення функцій, повноважень та відповідальності депутата місцевої ради); функціональну (розкриває організацію діяльності в напрямку ефективної взаємодії органів виконавчої влади та місцевого самоврядування в умовах децентралізації); оціночну (передбачає оцінювання ефективності місцевих органів виконавчої влади і органів місцевого самоврядування, а також діяльності депутата місцевої ради). Тому для аналізу європейського досвіду визначення статусу депутата місцевої ради (функціонування органів місцевого самоврядування) доцільно з'ясувати особливості по кожній із компонент.

Законодавчі орієнтири та політику в галузі місцевої і регіональної демократії визначено в положеннях Хартії місцевого самоврядування [2], яка є керівним документом серед міжнародних договорів держав-членів Ради Європи і сьогодні є частиною національного законодавства України. Серед основних положень, що стосуються визначення статусу депутата місцевої ради варто враховувати такі:

- 3 одного боку, органи місцевого самоврядування здійснюють регулювання та управління суттєвою часткою публічних прав в інтересах місцевого населення, а з іншого - $є$ “похідними" від суверенної державної влади;

- необхідність адаптації наданих місцевому самоврядуванню повноважень до місцевих умов (єдності державних і місцевих інтересів);

- визначення на законодавчому рівні головних повноважень і функцій органів місцевого самоврядування, а також можливості наділенню органів місцевого самоврядування повноваженнями та функціями для спеціальних цілей;

- визначення функцій чи діяльності, що несумісна з мандатом місцевого обраного представника;

- гарантованість права органів місцевого самоврядування на власні фінансові ресурси.

Виконаний нами аналіз європейських практик діяльності органів місцевого самоврядування загалом і статусу депутатів місцевої ради зокрема в окремих державах-члена $\mathrm{CC}$, дав змогу виокремити їх характерні риси, які представлені в Таблиці. 
Хоча Велика Британія офіційно 31 січня 2020 року вийшла зі складу СС, проте варто зосередити увагу на характерних особливостях діяльності органів місцевого самоврядування, що відрізняються від інших держав-членів ЄС. Кожна частина Сполученого Королівства Великої Британії [3-7] має чітку систему місцевого самоврядування. Місцеві органи влади мають дуже мало законодавчих повноважень і повинні діяти в рамках законів, прийнятих центральним парламентом (і парламентом Шотландії в Шотландії). Зокрема, характерною рисою у Великій Британії є “нецентралізація", за якої відбувається розширення функцій існуючої центральної влади і формується вичерпний перелік завдань органів місцевого самоврядування. При цьому органи місцевого самоврядування володіють лише тими повноваженнями, що надані їм парламентськими статутами, які $є$ наріжним каменем правової системи Британії. Для отримання додаткових повноважень органів місцевого самоврядування існує визначена законодавством процедура, яка $є$ досить складною і довготривалою. Цей процес передбачає звернення місцевих органів влади або до парламенту з проханням про видання відповідного “приватного" закону, або до державного секретаря (міністра), який вправі видавати відповідний указ.

Водночас органи місцевого самоврядування Великої Британії мають повноваження приймати постанови та стягувати податкові збори (податки на нерухомість) в межах, встановлених центральним урядом. Фінансування місцевих рад здійснюється за рахунок податків із бізнесу, плати за послуги та грантів Центрального уряду. Місцеві органи влади у Сполученому Королівстві відповідають за ряд громадських послуг, включаючи питання охорони навколишнього середовища, освіту, автомобільні дороги та рух транспорту, соціальні послуги, пожежні роботи, санітарію, планування, житло, парки та відпочинок, вибори. У Шотландії та Уельсі регіональні уряди виконують деякі 3 цих функцій, а місцеві органи управління - решту. У Північній Ірландії Асамблея Північної Ірландії відповідає за багато з цих функцій. Обов’язки органів місцевого самоврядування в Північній Ірландії обмежуються питаннями навколишнього середовища, санітарії та відпочинку.

У Великій Британії парафіяльні (ради графств) та міські ради утворюють найнижчий рівень місцевого самоврядування. Вони наділені повноваженнями здійснювати заходи, що стосується підтримки громади, рекреаційних об'єктів та якість навколишнього середовища, участь у процесі планування. Громадські ради виконують аналогічну роль у Уельсі, тоді як ради громад у Шотландії $\epsilon$ добровільними та консультативними органами, що мають мало статутних повноважень. Ефективність діяльності депутатів місцевих рад оцінюється 3 огляду на результати їх діяльності, що стосується: розробки пропозицій, які відповідають інтересам громади; планування та надання послуг та засобів для використання місцевими громадянами; побудова та зміцнення інфраструктури громади; розробка, прийняття і виконання місцевих законів. 
Контроль за діяльністю ради графств у Великій Британії здійснюється за кількома напрямами, серед яких: міністри (особливо міністри у справах місцевого самоврядування) видають обов'язкові інструкції для підконтрольних місцевих служб; типові інструкції міністерств можуть бути прийняті місцевими радами як зразки для власних регламентів; якщо за результатами роботи інспекції діяльність місцевих рад визнається незадовільною, повноваження останніх можуть бути передані чиновникам, які призначаються міністром, або іншим органам місцевого самоврядування.

Дещо схожі риси діяльності органів місцевого самоврядування представлені практичним досвідом Iсnанії [6-8]. Зокрема, передбачено чіткий розподіл повноважень органів державної влади та повноважень органів влади автономних територій, що закріплено у Конституції та впроваджено модель асиметричної децентралізації, що враховує переваги, потреби, досвід різних історичних регіонів. Це викликано культурними й історичними відмінностями між регіонами, а також нерівністю у їх економічному розвитку. Реорганізацію та демократизацію органів місцевого самоврядування визначено в Основному законі з питань місцевого самоврядування (Ley Reguladora de las Bases de Regimen Local). У зазначеному законі, 3-поміж іншого визначено розподіл обов'язків між різними рівнями управління, а також послуги, що мають надавати органи місцевого самоврядування.

В Іспанії існують два абсолютно різні режими децентралізації: спеціальний (мають повноваження щодо збирання податків на регіональному рівні, а всі основні види податків перебувають під адмініструванням регіональних органів влади) і загальний (повноваження щодо збирання податків значно обмежені). Обов'язки муніципалітетів змінюються пропорційно чисельності їх населення. Виключна компетенція держави передбачає перелік предметів відання та повноважень, які можуть здійснюватися лише органами державної влади та не можуть бути передані для вирішення органам місцевого самоврядування. Питання, що не віднесені Конституцією до виключної компетенції держави, можуть бути передані до компетенції автономних територій.

Для компенсації за послуги, які центральний уряд надає регіону, регіональний уряд виплачує центральній владі певну суму. Також регіони зі спеціальним режимом роблять внески до Фонду солідарності центрального уряду, який покликаний надавати інвестиційну підтримку бідним регіонам. Регіони загального режиму здійснюють адміністрування окремих податків, але не мають права встановлювати податкові ставки i визначати базу оподаткування.

Початковою територіальною одиницею Іспанії є муніципалітет, яким керує муніципальна рада. Члени муніципальної ради (радники) обираються мешканцями муніципалітету, а головою виконавчого органу муніципалітету алькальд, який обирається або мешканцями муніципалітету, або членами 
муніципальної ради. При цьому, ключова роль, що належить депутатам муніципальної ради являється в представленні інтересів певної політичної партії, а не лише інтересів муніципалітету. Ради в муніципалітетах, в залежності від кількості жителів можуть створювати свої правління, до складу яких може входити до третини від їх кількості.

Рівень відповідальності регіональних органів влади (широкий чи обмежений) може бути визначений місцевою громадою. За спеціального режиму децентралізації відповідальність за адміністрування податків передається автономному уряду. При функціонуванні загального режиму регіони мають значну відповідальність за розподіл ресурсів, але дуже мало автономії у частині збирання коштів.

В Італії, Франції та Німеччині в основі визначення функцій і повноважень органів місцевого самоврядування лежить принцип субсидіарності. За такого принципу місцеві органи влади, місцеві інтереси, місцеве самоврядування загалом не протиставляються державним, а навпаки інтегровані в єдиний управлінський механізм, діяльність якого спрямована на комплексне вирішення завдань, що постали перед суспільством у цілому [4]. Зокрема, акцентуючи увагу на характерних особливостях діяльності органів місцевого самоврядування варто відмітити, що в Imaлї застосовано модель автономії, де всі територіальні одиниці визначаються автономним утворенням 3 власним статусом. При цьому, законодавча влада належить державі та областям, встановлюючи при цьому сфери їх виключної, а також конкуруючої компетенції. Окрім того, визначення функцій та повноважень супроводжується двома протилежними процесами: на законодавчому рівні визначення такого комплексу завдань і функцій держави, який передається органам (комунам) ближчим до громадян, а також передачу комунами функцій, що $є$ “надкомунальними” за змістом у випадках, коли надані компетенції не можуть бути застосовані та здійснені в повному обсязі.

У Франизї $[4,6,7,9]$ застосовано таку модель децентралізації, де однією 3 головних засад вбачається підвищення здатності адміністративної системи відповідати щоденним потребам населення і сприяти реалізації місцевих проектів економічного розвитку. Децентралізовані рівні управління здобули більшу автономію і стали відповідальнішими за свої дії, а надання публічних послуг стало ще ефективнішим. В основу розмежування повноважень органів державної влади покладено конституційний принцип, згідно 3 яким територіальні колективи мають право приймати рішення у межах компетенції, що може бути надана їм. Тому повноваження різних рівнів публічної адміністрації чітко визначені законодавчо. Проте невеликі розміри території, мала чисельність населення окремих комун обмежують їх ресурси, а відтак і можливості належно здійснювати самоврядні повноваження без допомоги 3 боку держави. Для вирішення цього проблемного питання широкий спектр послуг населенню малих міст надають комуни інших видів, а центральний уряд 
фінансово допомагає комунам малих сіл через механізми фінансового регулювання. В цілому модель децентралізації у Франції поєднує, з одного боку, виборність всіх представницьких і виконавчих органів (мерів) місцевого самоврядування, а 3 іншого передбачає призначення представників 3 центральних органів влади на місця (тобто комісарів, префектів).

У Німеччині $[6,7,10]$ застосовано різні типи місцевого самоврядування, основні засади функціонування, організації та управління справами місцевої громади закладені в Основному законі Федеральної Республіки Німеччина та в конституціях Земельних Республік. У Німеччині важливим елементом децентралізації є такий розподіл повноважень, за якого держава допомагає більш слабким муніципалітетам, але при цьому не “забирає” функції та завдання у муніципалітетів, якщо вони можуть їх виконувати самостійно. Окрім того, завдання органів місцевого самоврядування розподіляються між районами, з одного боку, містами та муніципалітетами, з іншого, відповідно до принципу, що надлокальні послуги, які не можуть надавати муніципалітети, значною мірою надаються районами.

Муніципалітети представлені i легалізовані парламентами, який обирається загальними, прямими, вільними, рівними та секретними бюлетенями. Муніципальна рада (парламент) несе відповідальність за всі питання, які не передані міському голові. У деяких законодавчо визначених випадках муніципальній раді не дозволяється передавати свої повноваження щодо прийняття рішень комітету. Це включає випуск певних підзаконних актів та постанов, питань, що стосуються законодавства про державну службу та зайнятість, бюджетних та фінансових питань, питань, що стосуються власних та економічних компаній муніципалітету, а також заходи щодо аудиторської служби, які визначені більш детально.

Відносини місцевих адміністрацій до відповідної Землі дуже тісні. Це результат того, що міста, муніципалітети та райони $є$ конституційними елементами відповідної Землі. Вони безпосередньо інтегровані в адміністративну структуру Землі. Взаємозв'язки між Землями та відповідними місцевими органами проявляються у таких напрямках: повноваження регулювати i визначати повноваження органів місцевого самоврядування покладено на відповідні Землі; функції та повноваження муніципалітетів регулюються законами місцевого самоврядування кожної провінції.

Підстава для тісного взаємозв'язку між землями та "їх" місцевими органами влади лежить в Основному законі Федеральної Республіки Німеччина. Відповідно до розподілу обов'язків у Основному законі, повноваження регулювати право місцевого самоврядування покладено на Землю. Організація та обов'язки, права та обов'язки муніципалітетів регулюються таким чином законами місцевого самоврядування кожної провінції. 
В Україні реформу децентралізації розпочато в 2014 році і яку, за словами Віце-прем’єр-міністра - Міністра розвитку громад та територій Дениса Шмигаля планується завершити до кінця 2020 року [12]. 3 огляду на проведений аналіз статусу депутата місцевої ради за теоретичним, функціональним та оціночним компонентом (результати якого відображено у Таблиці) доцільно виділити окремі проблемні питання, що потребують вирішення.

По-перше, наявність політизації діяльності депутатів місиевої ради та закріплення впливу на нього великих політичних партій національного масштабу, що входить в суперечність з їх функціями та повноваженнями. Так, згідно з чинним законодавством в Україні (на відміну від Великої Британії, де все публічне управління на місцевому рівні спрямовано на реалізацію національних інтересів) функції та повноваження депутата місцевої ради передбачають реалізацію інтересів лише територіальної громади, виборців свого виборчого округу. Складність ситуації в Україні посилюється політизацією діяльності депутатів місцевих рад і закріпленні впливу різних політичних сил, які відстоюють різні ідеологічні та світоглядні цінності, стратегічні бачення шляхів розвитку держави. Така ситуація ускладнюється 3 набранням 1 січня 2020 року нового виборчого кодексу, за яким право висувати кандидатів на вибори до місцевої ради в Україні мають право лише політичні партії [13]. Очевидно, що саме великі політичні партії національного масштабу мають досить ресурсів на медіакампанію, $є$ впізнаваними настільки, щоб провести агітацію на території всього міста та набрати достатню кількість голосів. При цьому, невеликі регіональні партії втрачають можливість отримати частину мандатів, адже ресурсів для достатнього висвітлення в 3МI, іншої агітації, щоб набрати голосів на території відповідної територіальної громади у них немає.

По-друге, досить обмежено використовується інструмент співробітництва між об'єднаними територіальними громадами. Зокрема, на основі проведеного нами аналізу встановлено, що органи місцевого самоврядування (в тому числі й депутати місцевої ради) взаємодіють 3 органами виконавчої влади місцевого рівня, органами центральної влади, а також між двома або більше територіальними громадами, як наприклад це відбувається у Франції. Проте, з початку запровадження механізму взаємодії між об’єднаними територіальними громадами, тобто з 2014 року, по всій території України укладено лише 586 договорів. Також починаючи з 2019 року i по даний час укладено 203 договори про співробітництво між двома і більше територіальними громадами [14]. В той же час через різні можливості до самозабезпечення територіальних громад в значних обсягає реалізується участь держави у формуванні місцевих бюджетів, передачі необхідних коштів у вигляді дотацій і субвенцій. Зокрема, рівень дотаційності бюджетів за 9 місяців 2019 року Старосільської ОТГ (Рівнеська область) склав 65,9\%, 
Велимченської ОТГ (Волинська обл.) - 64\%, Ланчивської ОТГ (ІваноФранківська обл.) - 58,6\%, Вільшанської ОТГ (Львівська обл.) - 53,5\% дотації у доходах [15]. Але за ситуації з досить високим рівнем дотаційності бюджетів зазначених ОТГ, інструментом співробітництва між територіальними громадами скористалася лише Вільшаницька ОТГ, на відміну від ситуації у Франції, де досить поширеними є міжкомунні об'єднання.

По-третє, відсутні методологічні та інституиійні засади оиінювання ефективності діяльності депутата місцевої ради, як це, наприклад, реалізовано у Великій Британії. В Україні наразі законодавством визначено, що органи та посадові особи місцевого самоврядування підзвітні, підконтрольні та відповідальні перед територіальними громадами у форматі інформування населення про виконання програм розвитку територіальної громади. Передбачається запровадження Інституту префектів для здійснення ефективного нагляду за конституційністю та законністю рішень органів місцевого самоврядування. Окрім того, в Україні затверджено Порядок проведення оцінювання результатів службової діяльності державних службовців, дія якого поширюється на державних службовців, які займають посади державної служби категорій “А”, “Б” і “В” [16]. Проте, оцінювання ефективності діяльності депутатів місцевих рад у Великобританії, з огляду на результати їх роботи за визначеними критеріями, в Україні наразі не реалізовується.

Таблиця

Характерні риси діяльності органів місцевого самоврядування (статусу депутата місцевої ради) в окремих країнах-членах Європейського Союзу і Україні

\begin{tabular}{|c|c|c|c|}
\hline $\begin{array}{l}\text { Критерії } \\
\text { Країни } \\
\text { Базова } \\
\text { ланка } \\
\text { територіального } \\
\text { устрою }\end{array}$ & $\begin{array}{l}\text { Теоретичний } \\
\text { компонент }\end{array}$ & $\begin{array}{c}\text { Функціональний } \\
\text { компонент }\end{array}$ & Оціночний компонент \\
\hline $\begin{array}{l}\text { Велика } \\
\text { Британія } \\
\text { Ради графств }\end{array}$ & $\begin{array}{l}\text { Діяльність місцевих рад } \\
\text { поділяється на } 3 \text { основні } \\
\text { категорії: представлення } \\
\text { інтересів місцевої } \\
\text { громади, надання послуг } \\
\text { для задоволення } \\
\text { місцевих потреб, } \\
\text { прагнення покращити } \\
\text { якість життя та } \\
\text { добробут громади. } \\
\text { Все публічне управління } \\
\text { на місцевому рівні } \\
\text { спрямовано на } \\
\text { реалізацію національних } \\
\text { інтересів. }\end{array}$ & $\begin{array}{l}\text { Ради графств являються } \\
\text { вищими виконавчими та } \\
\text { вищими законодавчими } \\
\text { органами }\end{array}$ & $\begin{array}{l}\text { До обов'язків депутатів } \\
\text { місцевих рад з огляду на } \\
\text { ефективність їх } \\
\text { діяльності віднесено: } \\
\text { розробка пропозицій, які } \\
\text { відповідають інтересам } \\
\text { громади; планування та } \\
\text { надання послуг та } \\
\text { засобів для } \\
\text { використання } \\
\text { місцевими громадянами; } \\
\text { побудова та зміцнення } \\
\text { інфраструктури } \\
\text { громади; розробка, } \\
\text { прийняття і виконання } \\
\text { місцевих законів. Місцеві } \\
\text { ради мають виступати за } \\
\text { інтереси своєї місцевої } \\
\text { громади передіншими }\end{array}$ \\
\hline
\end{tabular}




\begin{tabular}{|c|c|c|c|}
\hline & & & $\begin{array}{l}\text { місцевими органами } \\
\text { влади та громадянами. У } \\
\text { цьому напрямку } \\
\text { ефективні члени ради є } \\
\text { відповідальними } \\
\text { партнерами уряду, коли } \\
\text { вони також враховують } \\
\text { потреби сусідніх громад. }\end{array}$ \\
\hline $\begin{array}{l}\text { Icnaнія } \\
\text { Муніципальна } \\
\text { рада }\end{array}$ & $\begin{array}{l}\text { Муніципальна рада не } \\
\text { ухвалює основні закони, } \\
\text { але розробляє } \\
\text { нормативно-правові } \\
\text { акти, що пов'язані із } \\
\text { законодавством } \\
\text { муніципальної ради. } \\
\text { Муніципальна рада } \\
\text { контролює розподіл } \\
\text { бюджету і може } \\
\text { встановлювати податки, } \\
\text { як доповнення до } \\
\text { дотацій центральних та } \\
\text { регіональних урядів. } \\
\text { Муніципальну раду } \\
\text { очолює міський голова, } \\
\text { який обирається з числа } \\
\text { членів ради, який в } \\
\text { більшості випадків } \\
\text { виконує функції лідера } \\
\text { партії більшості в раді. }\end{array}$ & $\begin{array}{l}\text { Центральний та } \\
\text { регіональний уряди } \\
\text { можуть делегувати } \\
\text { додаткові повноваження } \\
\text { муніципалітетам. } \\
\text { Відповідальність } \\
\text { муніципалітетів може } \\
\text { бути розділено з } \\
\text { обласними органами } \\
\text { влади у питаннях } \\
\text { охорони здоров'я та } \\
\text { освіти. } \\
\text { Урядом на } \\
\text { муніципальному рівні } \\
\text { керує муніципальна } \\
\text { рада, члени якої } \\
\text { обираються } \\
\text { безпосередньо } \\
\text { загальним виборчим } \\
\text { правом та відповідно до } \\
\text { пропорційного } \\
\text { представництва. } \\
\text { Міський головає } \\
\text { головою ради, керує } \\
\text { муніципальною } \\
\text { адміністрацією, } \\
\text { муніципальною } \\
\text { поліцією, має широкі } \\
\text { повноваження щодо } \\
\text { призначень, відіграє } \\
\text { важливу роль у зв'язках } \\
\text { з громадськістю. }\end{array}$ & $\begin{array}{l}\text { Ефективність } \\
\text { забезпечення суспільних } \\
\text { благ та послуг населення } \\
\text { на місцевому рівні } \\
\text { залежить від } \\
\text { спроможності } \\
\text { забезпечувати роботу } \\
\text { органів влади та } \\
\text { державних установ } \\
\text { паралельно з передачею } \\
\text { цим регіонам більшого } \\
\text { обсягу повноважень у } \\
\text { порівнянні з тими, що не } \\
\text { мають достатньої } \\
\text { адміністративної } \\
\text { спроможності. }\end{array}$ \\
\hline $\begin{array}{l}\text { Iталія } \\
\text { Комуни }\end{array}$ & $\begin{array}{l}\text { До відання комун } \\
\text { належить виконання } \\
\text { всіх адміністративних } \\
\text { функцій, за винятком } \\
\text { тих, що надані } \\
\text { провінціям, столичним } \\
\text { містам, областям та } \\
\text { державі } \\
\quad \text { Існує } \\
\text { Конституційна гарантія } \\
\text { підтримки вираженню } \\
\text { ініціативи громадянами } \\
\text { «комуни сприяють } \\
\text { самостійній ініціативі } \\
\text { громадян і їх об'єднань } \\
\text { щодо їх діяльності в }\end{array}$ & $\begin{array}{l}\text { Система } \\
\text { адміністративно- } \\
\text { територіального поділу і } \\
\text { управління в Італії } \\
\text { передбачає наявність } \\
\text { представника } \\
\text { центральної державної } \\
\text { влади у всіх } \\
\text { територіальних } \\
\text { одиницях. В області - } \\
\text { урядовий комісар, в } \\
\text { провінціях - префект, що } \\
\text { представляє } \\
\text { Міністерство внутрішніх } \\
\text { справ, в комунах - } \\
\text { синдик. }\end{array}$ & $\begin{array}{l}\text { Діяльність } \\
\text { контролюється } \\
\text { префектом, який } \\
\text { призначений } \\
\text { національним урядом. В } \\
\text { комунах представником } \\
\text { держави є синдик, в } \\
\text { обов'язки якого входить } \\
\text { постійне інформування } \\
\text { префекта про стан } \\
\text { громадського } \\
\text { правопорядку і безпеки. } \\
\text { Крім того за } \\
\text { необхідності } \\
\text { передбачається видання } \\
\text { відповідних }\end{array}$ \\
\hline
\end{tabular}




\begin{tabular}{|c|c|c|c|}
\hline & $\begin{array}{l}\text { суспільних інтересах на } \\
\text { засадах принципу } \\
\text { субсидіарності» } \\
\text { Комуни являють собою } \\
\text { невеликі } \\
\text { муніципалітети, основні } \\
\text { повноваження яких } \\
\text { спрямовані на соціально- } \\
\text { економічний розвиток } \\
\text { регіону, а також питань } \\
\text { благоустрою та } \\
\text { найбільш оптимального } \\
\text { використання прилеглих } \\
\text { до них територій. }\end{array}$ & $\begin{array}{l}\text { Представницьким } \\
\text { органом системи } \\
\text { місцевого } \\
\text { самоврядування є рада } \\
\text { комуни, що водночас } \\
\text { являється органом } \\
\text { політико- } \\
\text { адміністративного } \\
\text { контролю. Виконавчим } \\
\text { органом є дж унта } \\
\text { комуни, що забезпечує } \\
\text { виконання політико- } \\
\text { адміністративних } \\
\text { програм. }\end{array}$ & $\begin{array}{l}\text { нормативних актів, } \\
\text { направлених на надання } \\
\text { невідкладної допомоги в } \\
\text { сфері охорони здоров'я, } \\
\text { забезпечення гігієни, } \\
\text { координацію діяльності } \\
\text { місцевої поліції. }\end{array}$ \\
\hline $\begin{array}{l}\text { Франція } \\
\text { Комуна; } \\
\text { Представницький } \\
\text { орган - } \\
\text { муніципальна } \\
\text { рада }\end{array}$ & $\begin{array}{l}\text { Передано більшість } \\
\text { важливих повноважень } \\
\text { щодо забезпечення } \\
\text { життєдіяльності } \\
\text { територіальних } \\
\text { колективів та жителів } \\
\text { комун, зокрема: надання } \\
\text { різноманітних } \\
\text { соціальних послуг, } \\
\text { муніципальна поліція, } \\
\text { мережі автошляхів та } \\
\text { території комуни, } \\
\text { освітня та культурна } \\
\text { діяльність, } \\
\text { повноваження у сфері } \\
\text { міського та земельного } \\
\text { планування. Державою } \\
\text { також було надано } \\
\text { необхідні для цих } \\
\text { функцій ресурси } \\
\text { Комуни - невеликі } \\
\text { муніципалітети, основні } \\
\text { повноваження яких } \\
\text { спрямовані на соціально- } \\
\text { економічний розвиток } \\
\text { регіону, а також питань } \\
\text { благоустрою та } \\
\text { найбільш оптимального } \\
\text { використання прилеглих } \\
\text { до них територій. }\end{array}$ & $\begin{array}{l}\text { У межах комун відсутні } \\
\text { органи виконавчої влади } \\
\text { в особі призначуваних } \\
\text { урядом чиновників. } \\
\text { Функції представника } \\
\text { уряду в комуні виконує } \\
\text { мер комуни, що має } \\
\text { подвійний статус: він } \\
\text { одночасно представник } \\
\text { територіального } \\
\text { колективу та } \\
\text { представник держави в } \\
\text { комуні. Мер комуни } \\
\text { обирається } \\
\text { мунципальною радою. } \\
\text { Органи державної влади } \\
\text { виконують функцію } \\
\text { контролю над } \\
\text { діяльністю органів } \\
\text { місцевого } \\
\text { самоврядування. Ця } \\
\text { функція покладена на } \\
\text { префектів, правовий } \\
\text { статус яких також } \\
\text { змінився в бік звуження, } \\
\text { а саме до контрольних } \\
\text { функцій. } \\
\text { Для більш ефективного } \\
\text { виконання функцій } \\
\text { комуни можуть } \\
\text { утворюватися публічно- } \\
\text { правові міжкомунні } \\
\text { об'єднання, які } \\
\text { передбачають спільне } \\
\text { фінансування й } \\
\text { управління технічними } \\
\text { спорудами та } \\
\text { комунальними } \\
\text { службами, розробку } \\
\text { проектів у сфері } \\
\text { впорядкування } \\
\text { територій тощо. }\end{array}$ & $\begin{array}{l}\text { Досить жорстка система } \\
\text { контролю за діяльністю } \\
\text { комун. Уряд через своїх } \\
\text { представників - } \\
\text { префекта та } \\
\text { суперпрефекта - може } \\
\text { призупиняти виконання } \\
\text { рішень муніципальних } \\
\text { рад у разі їх } \\
\text { невідповідності законам. } \\
\text { Префекти реалізує } \\
\text { повноваження щодо } \\
\text { контролю за діяльністю } \\
\text { органів місцевого } \\
\text { самоврядування } \\
\text { департаментів і комун. }\end{array}$ \\
\hline
\end{tabular}


ISSN (print) 2618-0065

Науковий вісник: Державне управління №2(4) 2020

\begin{tabular}{|c|c|c|c|}
\hline $\begin{array}{l}\text { Німеччина } \\
\text { Мініципалітети; } \\
\text { Представницькі } \\
\text { органи - } \\
\text { муніципальні } \\
\text { ради }\end{array}$ & $\begin{array}{l}\text { Органи місцевого } \\
\text { самоврядування можуть } \\
\text { і повинні вирішувати всі } \\
\text { завдання, що не } \\
\text { вирішуються на } \\
\text { європейському, } \\
\text { федеральному, } \\
\text { регіональному рівнях, } \\
\text { щоб максимально } \\
\text { наблизити надання } \\
\text { публічних послуг до їх } \\
\text { споживача. } \\
\text { При цьому до } \\
\text { повноважень } \\
\text { муніципалітету, які не } \\
\text { можуть бути відібрані } \\
\text { належать такі } \\
\text { повноваження на: } \\
\text { організацію } \\
\text { адміністрації } \\
\text { муніципалітетів } \\
\text { самостійно; } \\
\text { облаштування території } \\
\text { муніципалітету під } \\
\text { власну відповідальність } \\
\text { (складання планів } \\
\text { містобудування); на } \\
\text { прийняття підзаконних } \\
\text { актів муніципалітету; } \\
\text { відповідальність за } \\
\text { управління своїми } \\
\text { доходами та витратами; } \\
\text { підвищення податків (за } \\
\text { умови, що це право не } \\
\text { було скасовано вищим } \\
\text { законом). }\end{array}$ & $\begin{array}{l}\text { Завдання громади } \\
\text { поділяються на } 3 \text { групи: } \\
\text { завдання, що } \\
\text { виконуються за } \\
\text { вказівкою (делеговані } \\
\text { державою } \\
\text { повноваження), } \\
\text { обов'язкові до } \\
\text { виконання самоврядні } \\
\text { завдання (виконуються } \\
\text { громадами відповідно до } \\
\text { законодавства земель), } \\
\text { самоврядні завдання, що } \\
\text { виконуються на } \\
\text { добровільній основі } \\
\text { (утримання спортивних і } \\
\text { культурних центрів, } \\
\text { створення молодіжних } \\
\text { центрів). }\end{array}$ & $\begin{array}{l}\text { Державний нагляд } \\
\text { здійснюється } \\
\text { державною виконавчою } \\
\text { владою, що здійснює } \\
\text { нагляд за правом } \\
\text { місцевої влади та } \\
\text { місцевої автономї та, де } \\
\text { це доцільно, обмежує її } \\
\text { на підставі закону. } \\
\text { Муніципальна рада може } \\
\text { організовувати } \\
\text { перевірку адміністрації } \\
\text { та виконання її рішень, } \\
\text { або через звіт міського } \\
\text { голови, або за участю } \\
\text { комітету чи репортера. } \\
\text { Однак муніципальна } \\
\text { рада не може отримати } \\
\text { право видавати } \\
\text { інструкції з права } \\
\text { перевірки. }\end{array}$ \\
\hline $\begin{array}{l}\text { Україна } \\
\text { Територіальна } \\
\text { громада }\end{array}$ & $\begin{array}{l}\text { Депутат місцевої ради як } \\
\text { представник інтересів } \\
\text { територіальної громади, } \\
\text { виборців свого } \\
\text { виборчого округу }\end{array}$ & $\begin{array}{l}\text { Взаємодія з органами } \\
\text { виконавчої влади } \\
\text { місцевого рівня } \\
\text { здійснюється шляхом: } \\
\text { заслуховування звіту } \\
\text { сільського, (селищного, } \\
\text { міського) голови про } \\
\text { діяльність виконавчих } \\
\text { органів ради, щорічного } \\
\text { звіту про здійснення } \\
\text { державної регуляторної } \\
\text { політики виконавчими } \\
\text { органами відповідної } \\
\text { ради; заслуховування } \\
\text { звітів постійних комісій, } \\
\text { керівників виконавчих } \\
\text { органів ради та } \\
\text { посадових осіб, яких } \\
\text { вона призначає або } \\
\text { затверджує; }\end{array}$ & $\begin{array}{l}\text { Органи та посадові } \\
\text { особи місцевого } \\
\text { самоврядування є } \\
\text { підзвітними, } \\
\text { підконтрольними і } \\
\text { відповідальними перед } \\
\text { територіальними } \\
\text { громадами. Вони не } \\
\text { менш як два рази на рік, } \\
\text { інформують населення } \\
\text { про виконання програм } \\
\text { соціально-економічного } \\
\text { та культурного } \\
\text { розвитку, місцевого } \\
\text { бюджету, з інших питань } \\
\text { місцевого значення, } \\
\text { звітують перед } \\
\text { територіальними } \\
\text { громадами про свою } \\
\text { діяльність }\end{array}$ \\
\hline
\end{tabular}




\begin{tabular}{|c|c|c|c|}
\hline & & $\begin{array}{l}\text { делегування } \\
\text { повноважень районних і } \\
\text { обласних рад } \\
\text { відповідним місцевим } \\
\text { державним } \\
\text { адміністраціям. } \\
\quad \text { Взаємодія з } \\
\text { органами центральної } \\
\text { влади шляхом: участі } \\
\text { держави у формуванні } \\
\text { місцевих бюджетів; } \\
\text { збалансування місцевих } \\
\text { бюджетів шляхом } \\
\text { передачі необхідних } \\
\text { коштів до відповідних } \\
\text { місцевих бюджетів у } \\
\text { вигляді дотацій та } \\
\text { субвенцій. } \\
\text { Взаємодія між двома або } \\
\text { більше територіальними } \\
\text { громадами з метою } \\
\text { забезпечення соціально- } \\
\text { економічного, } \\
\text { культурного розвитку } \\
\text { територій, підвищення } \\
\text { якості надання послуг } \\
\text { населенню на основі } \\
\text { спільних інтересів та } \\
\text { цілей, ефективного } \\
\text { виконання органами } \\
\text { місцевого } \\
\text { самоврядування їх } \\
\text { повноважень }\end{array}$ & \begin{tabular}{l}
\multicolumn{1}{c}{ Органи та } \\
посадові особи місцевого \\
самоврядування з \\
питань здійснення ними \\
делегованих \\
повноважень органів \\
виконавчої влади є \\
підконтрольними \\
відповідним органам \\
виконавчої влади. \\
\multicolumn{1}{c}{ Відповідно до } \\
законопроекту “Про \\
префектів” Інститут \\
перфектів передбачає \\
здійснення ефективного \\
нагляду за \\
конституційністю та \\
законністю рішень \\
органів місцевого \\
самоврядування і \\
з’являється після \\
набрання чинності \\
змінами до Конституції \\
щодо децентралізації та, \\
відповідно, після \\
ліквідації місцевих \\
держадміністрацій.
\end{tabular} \\
\hline
\end{tabular}

Побудовано за даними [4-11] 
Висновки. Таким чином, для визначення пріоритетів удосконалення правового статусу депутата місцевої ради в України в контексті реформи децентралізації доцільно враховувати результати порівняльної характеристики органів місцевого самоврядування (статусу депутата місцевої ради в державахчленах (C). Серед проблемних питань, що наразі потребують вирішення в Україні і стосуються удосконалення правового статусу депутата місцевої ради: наявність політизації діяльності депутатів місцевої ради та закріплення впливу на нього великих політичних партій національного масштабу; досить обмежене використання інструментів співробітництва між об'єднаними територіальними громадами; відсутність методологічних та інституційних засад оцінювання ефективності діяльності депутата місцевої ради. Для їх вирішення доцільним $\epsilon$ з'ясування функцій та повноважень депутата місцевої ради, що стосуються забезпечення взаємозв'язку реалізації національних інтересів та інтересів громади, а також ефективності їх діяльності. Не менш важливим питання $\epsilon$ врахування європейського досвіду окремих держав-членів $С$, що стосується організації взаємодії депутата місцевої ради іншими територіальними громадами, органами влади, що виконують функції контролю, а також 3 органами державної влади стратегічного рівня щодо реалізації національних інтересів.

\section{Лimepamypa:}

1. Джафаров Руслан Фикрет оглы Правовой статус депутата местного совета как предмет научных исследований. Публічне управління і адміністрування в Україні. 2018. Випуск 5. С.99-103

2. Європейська хартія місцевого самоврядування. Набрання чинності для України 01.01.1998 p. URL.: https://zakon.rada.gov.ua/laws/show/994_036

3. Local government. URL: https://www.britannica.com/place/United-Kingdom/Localgovernment\#ref751560

4. Хазанов Е.Н., Саудаханов М.В. Местное самоуправление европейских государств (на примере Соединенного Королевства Великобритании и Северной Ирландии, Французкой республики, Итальянской республики). Вестник Московского университета МВД Росии. 2017. №3. С. 158-161.

5. Lena Eisenstein. The Importance of Effective and Efficient Local Governments (2019). URL.: https://insights.diligent.com/workload-management/the-importance-of-effective-andefficient-local-governments

6. Бориславська О.М., Заверуха І.Б., Школик А.М. та ін. Децентралізація публічної влади: досвід європейських країн та перспективи України. Центр політико-правових реформ. Київ. 2012. 212 с.

7. Адміністративно-територіальний устрій країн Європейського Союзу: навч.посіб / за заг.ред. Ю.В.Ковбасюка, М.К.Орлатого. - К.: НАДУ, 2015. - 628 с.

8. "Democracy And local government in Spain: Evolution and trends in the interpretation of local autonomy”. URL: https://ecpr.eu/Filestore/PaperProposal/fff19d84-8267-42f6-97d4488dad4dfc7d.pdf

9. Жамулдинов В.Н., Комаров О.Е. Особенности французской модели децентрализации государственного управления и развития местного самоуправления. URL: https://scienceproblems.ru/osobennosti-frantsuzskoj/3.html 
10. Local Government Administration in Germany. URL: https://germanlawarchive.iuscomp.org/?p=380

11. Проект Закону України "Про префектів" (неофіційний текст). URL: https://ips.ligazakon.net/document/view/NT1780

12. Реформа децентралізації завершиться в 2020 році проведенням восени місцевих виборів на новій територіальній основі громад. URL: https://www.kmu.gov.ua/news/reformadecentralizaciyi-zavershitsya-v-2020-roci-provedennyam-voseni-miscevih-viboriv-na-novijteritorialnij-osnovi-gromad

13. Чому новий виборчий кодекс може зіграти злий жарт на місцевих виборах 2020. URL: $\quad$ https://uain.press/articles/chomu-novyj-vyborchyj-kodeks-mozhe-zigraty-zlyj-zhart-namistsevyh-vyborah-2020-1154975

14. Реєстр договорів про співробітництво територіальних громад (станом на 19.02.2020 року). URL: http://www.minregion.gov.ua/napryamki-diyalnosti/regional-dev/rozvytokmistsevoho-samovryaduvannya/reyestr/

15. Окремі показники виконання бюджетів ОТГ за 9 місяців 2019 року. URL: https://decentralization.gov.ua/news/11877?page $=2$

16. Про затвердження Порядку проведення оцінювання результатів службової діяльності державних службовців: постанова Кабінету Міністрів України від 23 серпня 2017 року № 640. URL: https://zakon.rada.gov.ua/laws/show/640-2017-\%D0\%BF

\section{References:}

1. Dzhafarov Ruslan Fikret ogly. (2018). Pravovoj status deputata mestnogo soveta kak predmet nauchnyh issledovanij [Legal status of a deputy of a local council as a subject of scientific research]. Publichne upravlinnya i administruvannya $v$ Ukrayini - Public management and administration in Ukraine, 5, 99-103 [in Russian]

2. Yevropejs 'ka xartiya miscevogo samovryaduvannya [European Charter of Local Self$\begin{array}{lll}\text { Government]. } & \text { (n.d.). } & \text { zakon.rada.gov.ua. } \\ \text { https://zakon rada.gov.ua/laws/show/994 } 036 \text { [in Ukrainian]. }\end{array}$
3. Local
government.
(n.d.)
britannica.com
Retreved from https://www.britannica.com/place/United-Kingdom/Local-government\#ref751560 [in English]

4. Hazanov E.N.\& Saudaxanov M.V. (2017). Mestnoe samoupravlenie evropejskih gosudarstv (na primere Soedinennogo Korolevstva Velikobritanii i Severnoj Irlandii, Francuzkoj respubliki, Ital'janskoj respubliki) [Local self-government of European states (based on the example of the United Kingdom of Great Britain and Northern Ireland, the French Republic, the Italian Republic)]. Vestnik Moskovskogo universiteta MVD Rosii - Bulletin of the Moscow University of the Ministry of Internal Affairs of Russia, 3, 158-161 [in Russian]

5. Lena Eisenstein. The Importance of Effective and Efficient Local Governments (2019). (n.d.) insights.diligent.com Retreved from https://insights.diligent.com/workloadmanagement/the-importance-of-effective-and-efficient-local-governments [in English]

6. Bory`slavs`ka O.M., Zaveruxa I.B., Shkoly`k A.M. et al. (2012). Decentralizaciya publichnoyi vlady`: dosvid yevropejs `ky`x krayin ta perspekty `v` Ukrayiny` [Decentralization of public power: experience of European countries and prospects of Ukraine] Kyiv: Center for Political and Legal Reforms [in Ukrainian]

7. Kovbasyuk Yu.V., Orlaty`j M.K. (Ed.) (2015). Administraty vno-tery`torial `ny `j ustrij krayin Yevropejs kogo Soyuzu [The administrative and territorial structure of the countries of the European Union]. Kyiv: NADU [in Ukrainian]

8. "Democracy And local government in Spain: Evolution and trends in the interpretation of local autonomy”. (n.d.) ecpr.eu Retreved from https://ecpr.eu/Filestore/PaperProposal/fff19d848267-42f6-97d4-488dad4dfc7d.pdf [in English] 
9. Zhamuldinov V.N.\& Komarov O.E Osobennosti francuzskoj modeli decentralizacii gosudarstvennogo upravlenija i razvitija mestnogo samoupravlenija [Features of the French model of decentralization of public administration and the development of local self-government]. scienceproblems.ru. Retreved from https://scienceproblems.ru/osobennosti-frantsuzskoj/3.html [in Russian]

10. Local Government Administration in Germany. germanlawarchive.iuscomp.org. Retreved from https://germanlawarchive.iuscomp.org/?p=380 [in English]

11. Proekt Zakonu Ukrayiny“ "Pro prefektiv” (neoficijny j tekst) [Draft Law of Ukraine “On Prefects” (unofficial text)] ips.ligazakon.net. Retreved from https://ips.ligazakon.net/document/view/NT1780 [in Ukrainian]

12. Reforma decentralizaciyi zavershy`t`sya v 2020 roci provedennyam voseny` miscevy`x vy`boriv na novij tery torial `nij osnovi gromad [Decentralization reform will be completed in 2020 by holding local elections on a new territorial basis for communities] kmu.gov.ua. Retreved from https://www.kmu.gov.ua/news/reforma-decentralizaciyi-zavershitsya-v-2020-rociprovedennyam-voseni-miscevih-viboriv-na-novij-teritorialnij-osnovi-gromad [in Ukrainian]

13. Chomu novy`j vy`borchy`j kodeks mozhe zigraty`zly`j zhart na miscevy`x vy`borax 2020 [Why the new election code may play a bad joke in the 2020 local elections] uain.press. Retreved from https://uain.press/articles/chomu-novyj-vyborchyj-kodeks-mozhe-zigraty-zlyjzhart-na-mistsevyh-vyborah-2020-1154975 [in Ukrainian]

14. Reyestr dogovoriv pro spivrobitny`cztvo tery `torial`ny`x gromad (stanom na 19.02.2020 roku) [Register of agreements on cooperation of territorial communities (as of 02/19/2020)] minregion.gov.ua. Retreved from http://www.minregion.gov.ua/napryamki-diyalnosti/regionaldev/rozvytok-mistsevoho-samovryaduvannya/reyestr/ [in Ukrainian]

15. Okremi pokazny`ky`vy`konannya byudzhetiv OTG za 9 misyaciv 2019 roku [Separate indicators of the implementation of the budgets for the 9 months 2019] decentralization.gov.ua. Retreved from https://decentralization.gov.ua/news/11877?page=2 [in Ukrainian]

16. Pro zatverdzhennya Poryadku provedennya ocinyuvannya rezul`tativ sluzhbovoyi diyal`nosti derzhavny`x sluzhbovciv: postanova Kabinetu Ministriv Ukrayiny` [On Approving the Procedure for Evaluating the Performance of Civil Servants: Resolution of the Cabinet of Ministers of Ukraine] (2017, August 23). zakon.rada.gov.ua. Retreved from https://zakon.rada.gov.ua/laws/show/640-2017-\%D0\%BF [in Ukrainian] 